\title{
A Comparative Study to Determine the Knowledge and use of Breast Self- Examination Technic among Female Student Nurses at St. Lukes School of Nursing, Rufunsa. Zambia
}

\author{
Article by Toddy Sinkamba \\ Nursing, Texila American University, Zambia \\ E-mail: toddkedsink@gmail.com
}

\begin{abstract}
Breast cancer is the second common cancer after cancer of the cervix in women in Zambia. Although screening methods for breast cancer such as mammography has been shown to reduce mortality from breast cancer in developing countries where it is commonly used, the World Health Organisation (WHO) does not recommend it for use in developing countries because of it has cost implications. Instead, WHO recommends an alternative screening method called Breast Self-Examination for all women in the reproductive age group (15-49). The purpose of the study was to compare breast cancer knowledge, attitude and use of Breast Self-Examination among female student nurses in the reproductive age group (15-49). The study site was St. lukes nursing school Rufunsa district of the Lusaka province in Zambia. A total of 50 female student nurses participated in the study.
\end{abstract}

Keywords: Breast cancer, Breast Self-Examination practice, Breast cancer knowledge, student nurses in year $2 \& 3$, Mammography.

\section{Introduction}

\section{Background information}

Breast cancer is one of the leading causes of death among middle-aged women and it is becoming a major public health problem developing countries including Zambia. The incidence rate of breast cancer has increased by $27 \%$ in blacks and $10 \%$ in whites over the past 30 years (Price 1992). It usually develops in women over 50 years but this trend has changed in the recent past as breast cancer is now being detected in pre-menopausal women. (Mukupo, 2006). At cancer diseases hospital, just the first quarter of 2017,37 cases were attended to at outpatient department compared to 21 during the same period in 2016 showing a $57 \%$ increase. (CDH, 2017).

The case detection and prevalence of breast cancer has continued to rise in Zambia, for instance, the incidence of breast cancer at the Cancer Diseases Hospital (CDH) increased from 21 in the first quarter of 2016 to 37 in 2007 (PIM, REPORT 2017). Data also showed that the disease was common in women aged 50 and above but now breast cancer is being recorded in women less than twenty years old. In 2002, 3 women less than 14 years were diagnosed with breast cancer and the incidence of those aged between 15 to 34 has risen from 13 in 2003 to 19 in 2003 (Mukupo, 2006).

It was noted that the above cases were just a minimal representation of breast cancer cases. There was still a problem of poor record keeping in the health institutions in the country. (mukupo 2006).

It was also reported that most women sought medical help in the late stage of disease. This could have been attributed to in adequate knowledge on the condition and non-utilisation of BSE as a screening tool by women.

Dorsey (2001) defines BSE as a method whereby a woman examines her breasts regularly and at specific intervals. According to Berkow (1997) the woman herself examines the breasts monthly one to two days after menstruation when the breasts are not tender or swollen. The monthly date of one's birthday or the first day of the month are common choices for many women. Available evidence showed that the sensitivity of BSE ranged from 60-65\% (Bailey 
2000; Humphrey 2002). BSE is a cost-effective self-care action, which when performed correctly can detect tumours of $2 \mathrm{~cm}$ or less, does not require specialised personnel or equipment as it can be performed at home by the individual in about 10 minutes (Bell 1997).

\section{Review of relevant literature}

Studies from around the world had shown that the incidence of breast cancer was rising both in developed and developing nations and that was common in menopausal women but this trend had changed in recent years (Bird 1992; Persson 1995). This change could have been as a result of changes in lifestyles especially in African women (Amir 1998). In the past women had started child bearing early, they reproduced many children and breast fed them for longer periods. In countries south of the Sahara, breast cancer was the second most common malignancy in women. In Uganda, the incidence was 16.4\% (Akhtar 1993) and in Tanzania breast cancer represented $8.1 \%$ of all female cancers with peak prevalence in the group 35-44 years (Zarubara 1999). Identified risk factors for breast cancer included early menache, nulliparity, late menopause, diet, physical exercise and hormonal factors (Amir 1994).

In addition, studies had shown that alcohol intake was associated with breast cancer and the risk increased slightly in women who consumed even one alcoholic drink daily but the risk doubled among women taking three drinks daily (Amir 1998; Dorsay 2001). Smeltzer (2000) had also suggested that smoking increased the risk of breast cancer and that the earlier women begun to smoke, the higher the risk.

\section{Objectives of the study}

\section{General}

To compare the knowledge, attitude /practice of BSE amongst student nurses and distinguish variation or association among the study variables

\section{Specific}

- To assess the knowledge of breast cancer and BSE among student nurses.

- To compare the knowledge of breast cancer and BSE among students in year $2 \& 3$.

- To assess the attitude/practice of students' nurses towards BSE

- To make recommendations to the General Nursing Council of Zambia

\section{Variables under study}

- Knowledge

- Attitude/ Practice

\section{Research methodology}

The study was conducted at St. lukes school of nursing-Mpanshya. The study design was exploratory and comparative in nature. Permission to conduct the study was obtained from the research ethics committee of the Institution and the General Nursing Council of Zambia authorities and informed consent was gotten from the individual students who participated in the study. The study units were female student nurses aged 16-49 years who were in year $2 \&$ 3. A total of 50 female student nurses participated in the study. The study adopted a systemic random sampling technique, using a sampling frame of intakes which has a total of 175 student population (nominal register, 2017).

The data-collecting instrument was a 28 -item semi structured interview schedule developed by the researcher. Face to face interviews were also conducted by the researcher. Each respondent was interviewed independently.

The research instrument comprised of three sections. Section a included elicited information on socio-demographic characteristics of the respondents. Section B was designed to obtain information on student's breast cancer knowledge. Section C elicited information on respondents' Breast Self -Examination altitude and practices. The instrument was pre-tested in order to assess validity and precision. After data collection, raw data was edited for 
completeness and consistency categorised and coded. EPI Info statistical package was used to analyse data. Excel spread sheet analysis was as well utilised to determine the association between variables.

\section{Research results}

The results are presented in tables and figures. A total of 50 respondents were interviewed. All the respondents were student nurses in year $2 \& 3$. Fifty-eight percent (58\%) of the respondents were from year 3 and $42 \%$ were from year 2 . The median age for year 2 students was 21 years and 23 for year 3 students. $70 \%$ of year 2 and $30 \%$ of year 3 students were married. Majority of the year 2 students (52\%) had one to five children, $2 \%$ had more than 5 children and $46 \%$ had never had child (Table 1).

With respect to educational attainment, $100 \%$ of year $2 \& 3$ had post-secondary education

As reflected in table 1, $19 \%$ of year 2 and $33 \%$ year 3 students were Catholics, $5 \%$ of year 2 students and $16 \%$ of year 3 belonged to United Church of Zambia and Pentecostal assemblies were 16\% from year 2 and $11 \%$ were from year 3 . The rest of the respondents $60 \%$ from year 2 and $40 \%$ from year 3 belonged to other churches.

Table 1. Socio-demographic characteristics of respondents

\begin{tabular}{|l|l|l|}
\hline $\begin{array}{l}\text { Socio demographic } \\
\text { characteristics }\end{array}$ & Year 2 n=21 & Year 3 n = 29 \\
\hline Year of study & $42 \%$ & $58 \%$ \\
Median age & 21 & 23 \\
Marital Status & $70 \%$ & $30 \%$ \\
married & $46 \%$ & $69 \%$ \\
Parity & $52 \%$ & $27 \%$ \\
Never had a Child & $2 \%$ & $4 \%$ \\
$1-5$ & $100 \%$ & $100 \%$ \\
$>5$ & $0 \%$ & $0 \%$ \\
Educational Attainment & $0 \%$ & $0 \%$ \\
Post-secondary & $19 \%$ & $33 \%$ \\
Secondary & $5 \%$ & $16 \%$ \\
Primary Education & $16 \%$ & $11 \%$ \\
Religious Affiliation & $60 \%$ & $40 \%$ \\
Catholics & \multicolumn{2}{|l}{} \\
United Church of Zambia & \multicolumn{2}{|l}{} \\
Pentecostal assemblies & \multicolumn{2}{|l}{} \\
Others & & \\
\hline
\end{tabular}

As regards knowledge about breast cancer, $58 \%$ of year 3 students had knowledge while $82 \%$ of year 2 students had no knowledge. Significant differences in knowledge were observed between the two (P0.000). Year 3 students were more knowledgeable about breast cancer than year 2 students (Figure $1)$. 
DOI: $10.21522 / \mathrm{TIJNR} .2015 .03 .02 . A r t 014$

ISSN: $2520-3126$

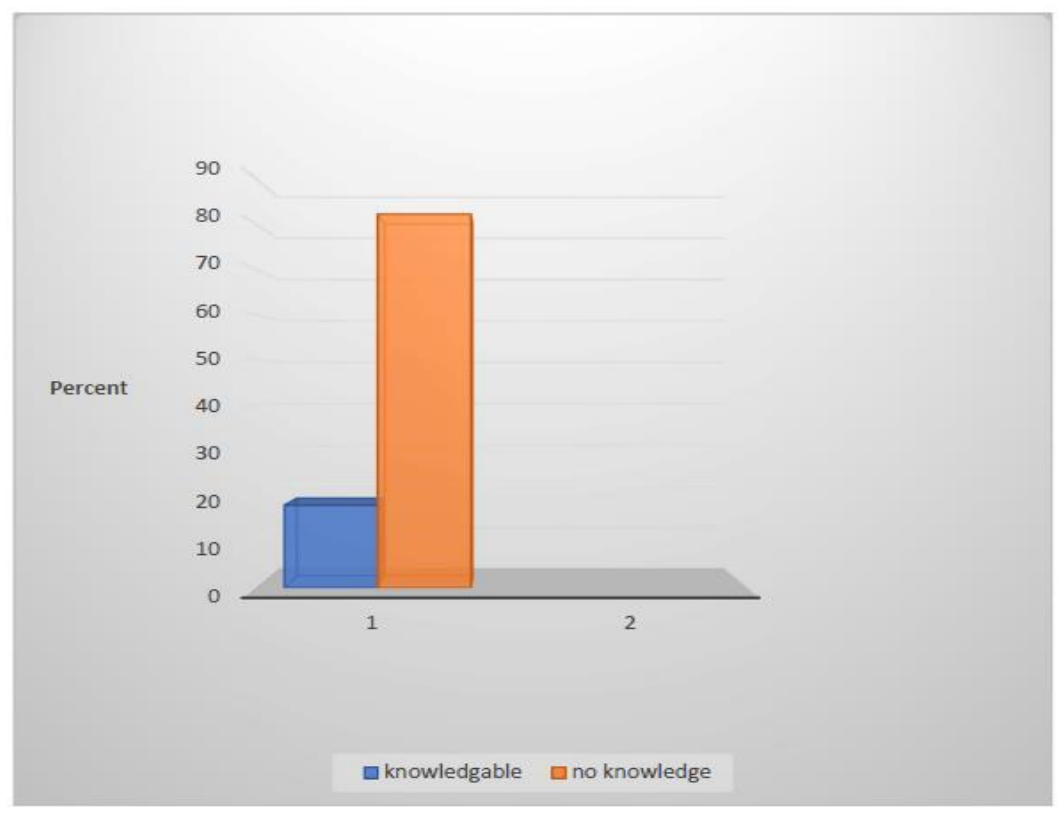

Figure 1. Breast cancer knowledge among students in year 2 and year 3 intakes

Figure 2. Show that $95 \%$ of year 3 students and $95 \%$ of year 2 students did not practice Breast SelfExamination. No significant differences were observed in BSE practice between year 3 and year 2 students (P 0.928).

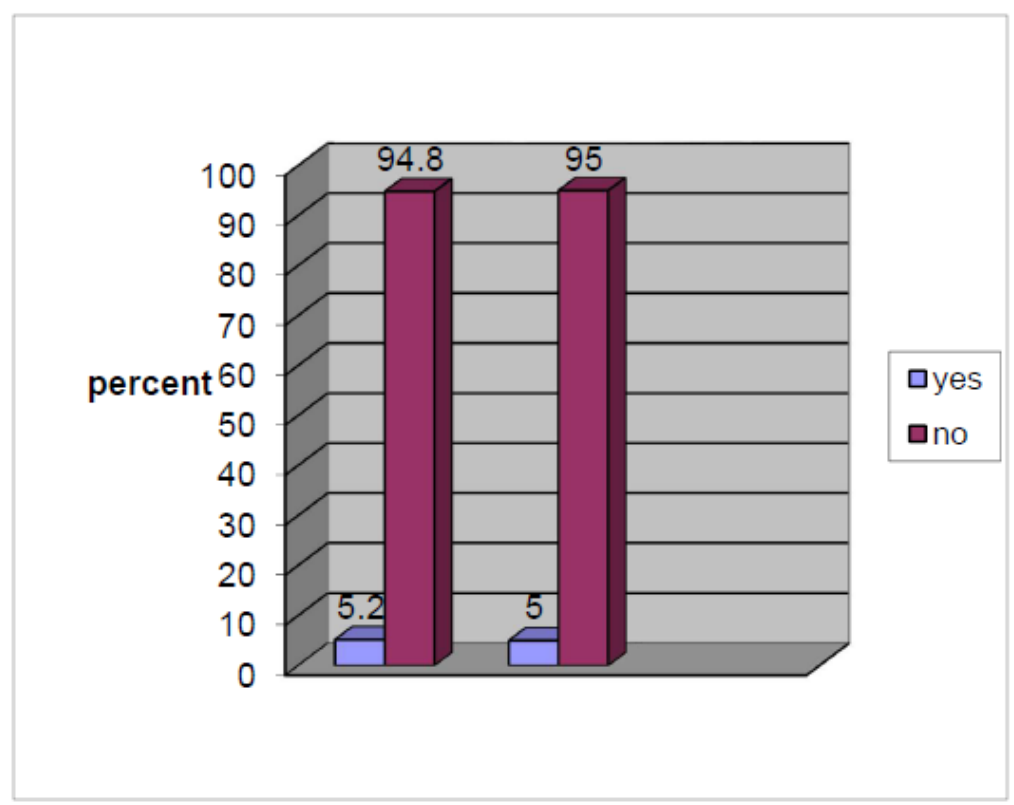

Figure 2. BSE practice among year 2 and year 3 students

The reasons given by both year 2 and year 3 students for not practicing breast self- examination were lack of knowledge on how to do the examination $\left(2^{\text {nd }}\right.$ year $, 88 \%, 3^{\text {rd }}$ year $89 \%$, ) did not think it was important $\left(2^{\text {nd }}\right.$ year $7 \%, 4$ (four) $3^{\text {rd }}$ year $\%$ ), did not perceive themselves to be at risk $\left(2^{\text {nd }}\right.$ year $0 \%, 3^{\text {rd }}$ year $0 \%$ ), I forget ( $2 \%$ year 3, $0 \%$ year 2) (Table 2). 
Table 2. Reasons for not practising BSE

\begin{tabular}{|l|l|l|}
\hline $\begin{array}{l}\text { Reasons for Non- } \\
\text { Practice of BSE }\end{array}$ & Year 3 n=21 & $\begin{array}{l}\text { Year 2 } \\
\mathrm{n}=29\end{array}$ \\
\hline Lack of knowledge & $89 \%$ & $88 \%$ \\
\hline $\begin{array}{l}\text { Did not think it's } \\
\text { important }\end{array}$ & $4 \%$ & $7 \%$ \\
\hline I forget & $2 \%$ & - \\
\hline
\end{tabular}

\section{Discussion of research findings}

In this study, the aspects of knowledge that were assessed included the definition, predisposing factors, signs and symptoms, treatment and prevention of breast cancer. The study revealed that both the $2^{\text {nd }}$ years and $3^{\text {rd }}$ year student's breast cancer knowledge levels were generally low. This could be attributed to lack of content in the nursing curricula as well as educational programs on breast cancer by curriculum developers and implementers and other concerned stakeholders and this has limited access to accurate information by students. In adequate knowledge on breast cancer could have led to students not practicing Breast Self- Examination (Leslie 2003; Macdonald 1999; Nzarubara 1999; Price 1992; Sadler 2001). A similar result was obtained in an American and Zambia study where women's knowledge levels about breast cancer were low (Leslie 2003, Mukupo 2006). Students need to know the dangers of breast cancer so that they can effectively pass on the knowledge and skill to mothers whose information could be communicated to women during antenatal, postnatal clinics visits and through electronic and print media. It is quite clear that education on breast cancer could promote early diagnosis of the condition and women would see the need to do breast self-examination.

The results however showed significant differences in breast cancer knowledge between year 2 and year 3 students ( $\mathrm{P}$ 0.000). Knowledge level was higher in year 3 students compared to year 2 counterparts. The differences in knowledge levels could due to easy access to information and level of training by year 3 students than their colleagues.

Many students in both year 2 and year 3 intakes did not practice breast self- examination. This could be attributed to lack of specific information about breast self- examination as a screening tool. According to Steinberger (1994) and Ko (2000), knowledge of breast cancer and provision of screening guidelines is related to high screening rates. The major reasons cited by the students for not practicing Breast Self- Examination included lack of knowledge and skill on how to perform breast selfexamination, they did not think it was important to examine themselves, and that they did not perceive themselves to be at risk. Barton (1999) and Budden (1995) also found that many women in America gave similar reasons for not practicing Breast Self-Examination. Mukupo 2006, also found similar reasons.

\section{Conclusion}

The findings showed that a large percentage of year 2 students had no knowledge about breast cancer than year 3 students. A significant difference in knowledge levels on breast cancer was observed between the two intakes. Students in year 3 intake had more knowledge on breast cancer than their counterparts in $2^{\text {nd }}$ year. Breast Self-Examination practice was poor in both intakes. They mutually did not practice Breast Self- Examination.

\section{Recommendations}

Based on the research results the following recommendations were made:

- The General nursing council of Zambia should review the content on breast cancer in the curriculum and incorporate the tutors and peer educators as master trainers on the dangers of breast cancer and breast self -examination so that they are equip student nurses that will in turn educate communities on the dangers of breast cancer and breast self- examination.

- The Government should develop a policy on breast screening. Breast Self- Examination should be recommended as the best method of screening for cancer of breast in Zambia.

- Educational programs on breast cancer and Breast Self-Examination should be conducted on electronic and print media by Ministry of Health 
DOI: $10.21522 /$ TIJNR.2015.03.02.Art014

ISSN: $2520-3126$

- The Ministry of Health and other concerned stakeholders should develop teaching manuals and other teaching aids for use by health providers so that there is consistency and uniformity in the information given to women.

- Breast cancer and breast self-examination should be incorporated in the Zambian school curricular so that girls in schools are sensitised at an early age.

- A more rigours study to be conducted on the topic in order to shed more light on the subject matter.

\section{References}

[1].Abdel-Fattah, M., et al, (2000). Breast self-examination practice and its impact on breast cancer diagnosis in Alexandria, Egypt. Eastern Mediterranean Health Journal. Volume 4. No. 2. PP 34-40.

[2].Akhtar, S.S., et al, (1993). Cancer in Libya- A Retrospective Study 1981-1985. African Journal of Medicine and Medical Sciences. Vol .22. No 1, PP 17-

[3].American Cancer Society (1999). Cancer Related Check- Ups; Atlanta G.A.

[4].Amir, H., et al, (1994). A Comparative Study of Carcinoma Of The breast in African Population; East African Journal, Volume 71. No. 4, PP 215-218

[5].Amir, J.T., et al, (1998). Breast Cancer and Risk Factors in an African Population: A Case Referent Study. East Africa Medical Journal. Volume 75. No. 5, PP 268-270.

[6].Anim, J.T., (1993). Breast cancer in Sub Sahara African Women. African Journal of Medicine and Medical Sciences. No 1. PP 5-10

[7].Attai, A.K., et al, (1997). Effects of Educational Film on Health Belief Model and Breast Self-Examination practice. Eastern Mediterranean Health Journal. Volume 3. No. 3. PP 435-443.

[8].Bailey, K., (2000). The Nurse's Role in Promoting Breast Awareness. Nursing Standards. Vol.14. No. 30. PP 34-36.

[9].Bell, R., et al, (1997). The Impact of Wellness: Guide on Hispanic Women's Well Being. Related Mediating Role of Enculturation; Health Education and Behaviour; Volume 24. No. 3. PP 326-343.

[10]. Berkow, R., (1997). The Merck Manual of Medical Information. Merck Research Laboratories. Whitehouse Station. New Jersey. PP 796, 1096-1107.

[11]. Budden, L., (1995). Young Women's Breast Self-Examination and Practice. Journal of Community Health Nursing. Vol. 12. No. 1, PP23-32.

[12]. Cancer Diseases Hospital, (2017) PIM. Report. $1^{\text {st }}$ quarter 2017, Lusaka, Zambia

[13]. Cancer Registry, (2003). Cancer Annual Report. University Teaching Hospital. Lusaka. PP 1-30 Care. Mosby Company. Chicago.

[14]. Central Stastical Office, (2002-2003). Demographic and Health Survey Report. Lusaka. PP 29-45

[15]. Central Statistical Office, (2003). Zambia 2000 Census of Population and Housing Summary Report. Lusaka. PP 28-35

[16]. Champion, V.L., (1995). Results of a Nurse-delivered intervention on Proficiency and Nodule detection with breast self-examination. Oncology Nursing Forum. Vol.22. No 5. PP 819-824.

[17]. Chee, H.L, et al., (2003). Factors Related to the Practice of BSE and Pap smear Screening among Malaysian Women Workers in the Selected Electronics Factories. BMC Women's Health. Vol. 3. PP3.

[18]. Dorsay, R.H., et al., (2001) Breast Self-Examination. Improving Competence and Frequency in a Classroom Setting. American Journal of Public Health. Vol. 78. No. 5, PP520-522

[19]. Epstein, S. S., et al (1998). The Breast Cancer Prevention Program. Macmillan, New York, 1998.

[20]. Epstein, S. S., et al (2001). Dangers and Unreliability of Mammography: Breast Examination is a Safe, Effective and Practical Alternative. International Journal of Health Sciences. vol.31 No. 3 PP 605-615

[21]. Gastrin, G., et al. (1994). Incidence and mortality from Breast cancer in the Mama program for Breast Screening in Finland, 1973-1983, No 73. pp 2168-2174.

[22]. Gotzsche, P. C. et al (2000). Is screening for breast cancer with mammography justifiable? Lancet 355: 129134.

[23]. Government Republic of Zambia, (2000). National Gender Policy Report .Lusaka. PP 38-49.

[24]. Harkness, G.A. et al (1996). Medical surgical Nursing. Total Patient

[25]. Heitkemper, L.C., (1996). Medical Surgical Nursing: Assessment and Management of Clinical Problems. Mosby Company. Chicago. PP 1548-1549. 
[26]. Hill, D. et al, (1988) Self-examination of the Breast: Is it Beneficial? Meta-Analysis of Studies Investigating BSE and the Extent of Disease in Patients with Breast Cancer. British Medical Journal. PP 271-297.

[27]. Janda, M., et al, (2000). Australian Women's Attitude towards and Knowledge of Breast self-examination. Journal of Cancer Education. Volume 15. No. 2. PP 91-94.

[28]. Janda, M., et al, (2000). Australian Women's Attitude towards and Knowledge of Breast self-examination. Journal of Cancer Education. Volume 15. No. 2. PP 91-94.

[29]. Kartz, L., et al, (1981). The Epidemiological Review of Breast Cancer in Israel. Israel Journal of Medical Sciences. Vol 19. No 9, PP 810-815.

[30]. Kartz, L., et al, (1981). The Epidemiological Review of Breast Cancer in Israel. Israel Journal of Medical Sciences. Vol 19. No 9, PP 810-815.

[31]. Knobf, T.M., (1990). Early-Stage Breast Cancer. The Options. American Journal of Nursing. PP 28-29.

[32]. Knobf, T.M., (1990). Early-Stage Breast Cancer. The Options. American Journal of Nursing. PP 28-29.

[33]. Ko, C., et al, (2000). Fillipina American Women's breast cancer knowledge, attitude and screening behaviour. BMC Public Health. Volume 3. PP 27

[34]. Ko, C., et al, (2000). Fillipina American Women's breast cancer knowledge, attitude and screening behaviour. BMC Public Health. Volume 3. PP 27

[35]. Leight, S. B., et al, (2000). The effect of structured training on breast self- examination search behaviors as measured using biomedical instrumentation. Nursing Research. Vol. 49 No 5.pp 283- 289.

[36]. Leight, S. B., et al, (2000). The effect of structured training on breast self- examination search behaviors as measured using biomedical instrumentation. Nursing Research. Vol. 49 No 5.pp 283- 289.

[37]. Leslie, N.S., et al, (2003). Knowledge, Attitude, Practice Surrounding Breast Cancer Screening in Educated Appalachian Women. Oncology Nursing Forum. Vol. 30. No. 4. PP659-667.

[38]. Leslie, N.S., et al, (2003). Knowledge, Attitude, Practice Surrounding Breast Cancer Screening in Educated Appalachian Women. Oncology Nursing Forum. Vol. 30. No. 4. PP659-667.

[39]. Lewis, S.M., et al, (1996) Medical surgical Nursing. Assessment and Management of Clinical Problems. C.V. Mosby. Chicago.

[40]. Lewis, S.M., et al, (1996) Medical surgical Nursing. Assessment and Management of Clinical Problems. C.V. Mosby. Chicago.

[41]. Mahajan, B., (997). Methods in Biostatstics for Medical Students and Researchers. Medical Publishers. Calcutta. PP 97-98

[42]. McDonald, P. A., et al, (1999). Perceptions and knowledge of Breast Cancer among African-American women residing in Public Housing, Ethnic Dis. Vol. 9. No 1. PP81-93.

[43]. McMahon, E., et al., (1993). Diseases. Causes and Complications. Assessment Findings. Nursing Diagnoses and Interventions. Patient Teaching and Current Therapy. Springhouse. Pennsylvania. PP 276-278.

[44]. Meissner, H.I., (1992). How Resources of Health Information Relate to Knowledge and Use of Cancer Screening Exams. Journal of Community Health. Vol. 17. No. 3, PP 153-165.

[45]. Mukupo, (2006) SBE, RURAL \& URBAN WOMEN, LUSAKA ZAMBIA.

[46]. Nzarubara, R.G., (1999). Control of breast Cancer Using Health Education. East African Journal of community Medicine. Vol. 76. No. 12, PP 661-663.

[47]. Orem, D., (1999). Nursing Concepts of Practice. Mosby Co. St. Louis.

[48]. Orzturic, M., et al, (1999). The practice of BSE among women in Gullistan District of Isparta. Eastern Journal of Medicine. Vol. 4. No. 2 PP 47-50.

[49]. Park, K., (2002). Park's Textbook of Preventive and Social Medicine. M/s Banarsidas Bhanot Publishers. Jabalpur. PP 291-292

[50]. Patistea, E., et al, (1992). Breast self-Examination: Knowledge and behaviour of Greek female health care Professionals Working in Primary Health Care Centres. Cancer Nursing. Vol. 15. No. 6. PP 415-442.

[51]. Patton, Q. M., (1990). Qualitative Evaluation and Research Methods. Sage Publication International. London.

[52]. Peragallo, N.P., et al, (1998). Breast Care among Latino Immigrant Women in the United States. Health Care for Women International. Vol. 19. PP 101-108.

[53]. Peragallo, N.P., et al, (2000). Acculturation and Breast Self-Examination among Immigrant Latin Women in the USA. International Council Review. Vol. 47. No. 1. PP 38-45. 
DOI: $10.21522 / \mathrm{TIJNR} .2015 .03 .02 . A r t 014$

ISSN: $2520-3126$

[54]. Persson, K., et al, (1995). Breast Self-Examination among Swedish Women: A survey of Frequency, Knowledge and Attitudes. Journal of Cancer Education. Vol.10. No3. PP 163-167

[55]. Polit, D., (1995). Nursing Research. Principles and Methods. J.B. Lippincott Company. Philadelphia

[56]. Polit, D., et al (1999). Nursing Research. Principles and Methods. J. B. Lippincott Company. Philadelphia.

[57]. Powel, E., et al, (1987). The Diagnosis and Detection of Breast Disease. Mosby Co. Chicago. PP 71-75

[58]. Price, J.H., (1992). Urban Black Women's Perceptions of Breast Cancer and Mammography. Journal of Community Medicine. Vol. 17. No. 4, PP 191-203.

[59]. Quinn, F.M., (1997). The Principles and Practice of Nurse Education. Stanley Thornes Publishers Ltd. London.

[60]. Sadler, G.R., et al (2001). Korean Women; Breast Cancer Knowledge, Attitude and Behaviours. BMC Public Health. Vol. 1. No. 7. PP1471-2458.

[61]. Sample. (n.d.). The American Heritage ${ }^{\circledR}$ New Dictionary of Cultural Literacy, Third Edition. Retrieved June 4, 2017 from Dictionary.com website http://www.dictionary.com/browse/sample

[62]. Smeltzer, C.S., et al, (2000). Textbook of Medical Surgical Nursing. Philadelphia. Toronto. PP 1268-1268

[63]. Smigel, K. (1993). Perception of risk heightens stress of breast cancer. Journal of National. Cancer Institute. Vol. 85. No 7. PP 525- 526

[64]. Steinberger, C., (1994). Breast Self-Examination: How Nurses can influence Performance. Medical Surgical Nursing. Vol. 3. No.5.PP 367-371

[65]. Utilisation and Associated Factors. American Journal of Public Health. Vol.79. No. 11. PP1499-1501.

[66]. Van Loon, J.M., et al, (1994). Socio economic Status and Breast Cancer Incidence: A Prospective Cohort Study. International Journal of Epidemiology. Vol. 23.No 5. PP 899-905.

[67]. Virobiof, D.A., et al, (2001). Cancer Incidence in South Africa. Journal of Clinical Oncology. Vol. 19. (18 Supplement) PP 1255-1275.

[68]. Worden, J. K., et al, (1990). A community-wide program in breast self-examination. Preventive Medicine. Vol. 19. PP 254- 269.

[69]. Zapka, J.K., et al, (1989). Breast Cancer Screening by Mammography.

[70]. Zapka, J.K., et al, (1992). Changes in Mammography Use: Economic, Need and Service Factors. American Journal of Public Health. Vol. 82. No. 10, PP 1345-1355. 